\title{
ビアテイスト飲料の摂取が認知課題の遂行に及ぼす影響
}

\author{
青山謙二郎 \\ (同志社大学文学部) \\ Key words: ノンアルコールビール ビアテイスト飲料 条件性補償反応
}

薬物に対して耐性が生じる原因の少なくとも一部が古典的 条件づけであるという説がある（例、Siegel, 1978）。例えば、 ビールを繰り返し摂取することにより生じるアルコールに対 する而性は、ビールの風味を条件刺激（C S ）、アルコールを 無条件刺激（US） とする条件づけの結果、アルコールに対 する無条件反応である酩酊作用と拮抗する反応が条件性補償 反応として生じた結果、ビールを飲んでも酩酊反応が出現し にくくなるといった考えである。この考えに基づけば、普段 からビールを飲む習慣のある人がビアテイスト飲料（ノンア ルコールビール）を飲んだ場合、ビールの風味（C S ）は存 在するが、U S であるアルコールがほとんど存在しないため 無条件反応である酩酊反応は生じず、それと拮抗する条件性 補償反応のみが出現し、認知課題の成績が向上すると考えら れる。本実験ではこの予測について検討した。

\section{方 法}

実験参加者 平均して一週間に 1 回以上ビールを飲む習慣 のある 20 歳以上の大学生を対象に実験への参加を呼びかけ、 26 名（男性 24 名、女性 2 名）が実験に参加した。平均年齢 は2 1.5 歳 $(S D=1.9$ 歳) であった。無作為に実験群 12 名と統 制群 14 名に配分した。

課題 以下の 4 つの課題を実施した。なお、1）と 2）の 1 試行は 2 分間、3）と 4）の 1 試行は 1 分間であった。

1)アルファベットの間違い探し A4 用紙 2 枚に印刷された アルファベットの文字列（横 14 字、縦 24 列）を比較し、1 枚目と 2 枚目で異なる部分を見つけ、丸をつけさせた。

2 ）文章の間違い探しは、A4 用紙 2 枚に印刷された簡単な物 語文 (「ごんぎつね」など) を読み、漢字やひらがなが間違っ ている部分、文字が余分に入っていたり欠けていたりする部 分を見つけ、その部分に丸をつけさせた。

3 ) 単純反応課題 A4 用紙 1 枚に $\square$ のマスが $15 \times 15$ で配置

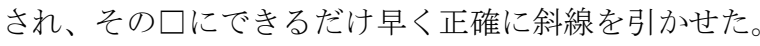

4 ) 強制選択課題 9 種類の図形とそれに対応して1〜9まで の数字が事前に設定されており、A4 用紙 1 枚に $23 \times 4$ でラン ダムな順序で配列された図形の下の $\square マ$ スに対応した数字を 記入させた。

手続き 実験には一度に最大 4 名以内で参加してもらった。 実験参加者が来室すると着席させ、実験の同意書に署名の後、 飲酒習慣に関する調査紙に回答させた。この時点で飲料の種 類を実験参加者に伝え、ビアテイスト飲料を飲む実験群のみ 呼気中アルコール濃度を測定した。その後実験全体の流れを 説明し、説明後に「酔った感じだ」など 5 項目に関する気分 評定を 7 件法で行わせた。

次に、4つの課題の説明を行い、順に実施した。課題終了 後に、10 分間で飲物を飲ませた。実験群ではビアテイスト飲 料 $(350 \mathrm{ml})$ 、統制群では水、茶、炭酸飲料水のどれか一種類 （340 から $350 \mathrm{ml}$ ) を飲んだ。実験群ではごく少量（0.1\%未 満）のアルコールしか含まれていないことを教示し、飲んだ 直後に呼気中アルコール濃度を測定し、アルコールが検出さ れないことを参加者にも確認させた。

その後、気分評定と 4 種の課題のセットを 3 回繰り返した。 最後に実験群では呼気中アルコール濃度を測定し、アルコー ルが検出されないことを確認した。

\section{結果と考察}

実験群と統制群の比較 気分評定の「酔った感じだ」の項目 に関して、有意な群の主効果 $(F(1,24)=4.95, p<.05)$ と有意傾 向の交互作用 $(F(3,72)=2.29, p<.10)$ が見られ、実験群でビア テイスト飲料摂取後に酔った感じが生じていた。他の項目 (楽 しい気分だ、イライラ寸る、不快な気分だ、頭がすっきりす る）に関しては有意な群の主効果、交互作用は見られなかっ た。また、課題については、全ての課題において、実験群と 統制群の間に有意な差異は認められなかった。これらの結果 は、目的で述べた予測を支持しないものであった。

実験群で酔いを感じた群と感じなかった群の比較 実験群 において、飲む前に「酔った感じだ」の評定が「全くあてはま らない（1 点)」であったが、飲料を飲んだ後評定の得点がそ れよりも増加（2４ 点）した実験参加者を有酔群（7名）、得 点が 1 点のまま変化しなかった実験参加者を無酔群（4名） とし、2 群間での比較を行った（飲料を飲む前から「酔った感 じだ」の得点が 3 点だった 1 名は分析から除外した)。

飲酒頻度、飲酒量、飲酒歴、年齢、前日の睡眠時間に関す る $t$ 検定の結果、飲酒頻度のみに有意な差が見られ $(t(9)=2.27$, $p<.05$ )、有酔群（月 5.7 回）よりも無酔群（月 8.5 回）の方が 飲酒頻度が高かった。

有酔群、無酔群の各課題における平均值と $S E M$ を図 1 に示 す(統制群の結果も参考のために示した)。文章間違い探し課 題と強制選択課題に有意な交互作用が見られ（順に $F(3,27)=4.64,2.52, p s<.05)$ 、他の課題には差が見られなかった。 文章間違い探し課題、強制選択課題ともにビアテイスト飲料 を飲んだ後に無酔群は成績が向上したが、有酔群では向上が ほとんど見られなかった。つまり、実際にはアルコールをほ とんど含んでいないビアテイスト飲料を飲んだ場合にも、主 観的に酔ったと感じる人は酔ったと感じない人よりも、課題 の成績が相対的に悪くなることが示された（研究の遂行にあ たり、同志社大学文学部心理学専攻 2003 年度生島崎紗代さん と吉岡未早さんの協力を得たことを感謝します。)
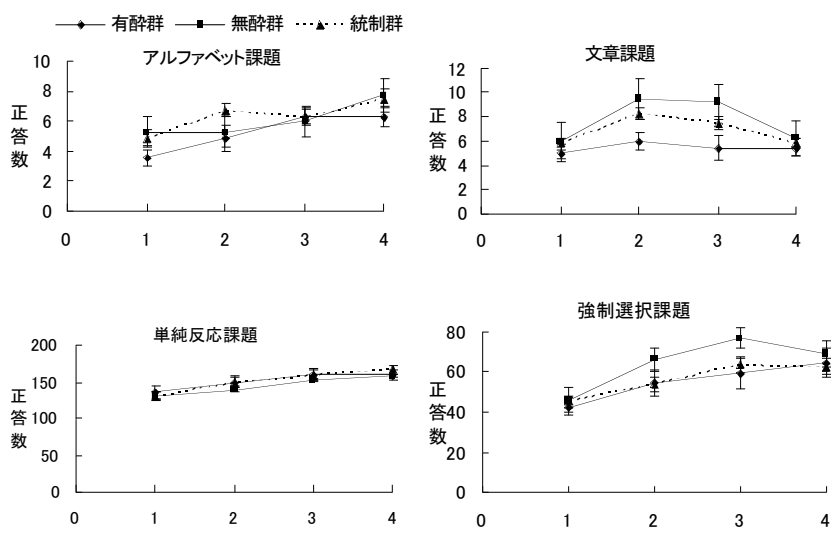

図 1 各課題の成績 ( 1 回目のみが飲料摂取前)。

\section{引用文献}

Siegel, S. (1978). Journal of Comparative and Physiological Psychology, 89, 498-506.
(AOYAMA Kenjiro) 